\title{
真理を発見する装置
}

— Habermas社会理論におけるコミュニケーションの役割

\section{A Device to Discover the Truth:}

The Role of Communication in Habermas's Social Theory

\section{伊藤 賢一 ITO Kenichi}

Much attention has been paid recently to the social theory of Jürgen Habermas. However, it has also attracted strong criticisms from broader academic fields. One of the criticisms comes from feminism theorists, focusing on his ideally proposed conception of public sphere.

This paper examines Nancy Fraser's criticism as a typical example to point out that she may be underestimating the power in Habermas's social theory. Although most of her commentaries make sense, they nevertheless tend to overlook the role of communication (or discourse) in his theory, which operates as a device for discovering (or to approaching) the truth.

\section{1.はじめに}

Habermasの社会理論が英語圈に知られるようになるにつれて、多方面からの批判も出て くるようになった。それも社会学だけでなく、哲学的正義論や道徳・政治哲学・教育学・ 歴史学・メディア論といった多方面から様々に批判されるようになってきている（最近の ものとしては、White (ed.) [1995]、Deflem (ed.) [1996]、ジェイ（編）[1997］など)。 その中でも、フェミニズムからの反応は無視できないものである。というのは、フェミニ ズムからの既存学問批判がそうであったのと同じく、その批判がラディカルで徹底してい るからである。

本稿は、そうした批判の典型的なものとしてNancy Fraserのものをとりあげる。特に Fraserの議論をとりあげるのは、彼女の議論が明晰で的確であるだけでなく、多くのフェ ミニストからの批判に共通する、重要な論点を含んでいるからでもある(1)。Habermasの議 論は現在も発展過程にあり、こうした批判を部分的に取り入れる形で修正がなされている が、Fraserらの批判は依然として有効性を無くしてはいない。特に批判の集中しているブ ルジョア公共圏（Öffentlichkeit / public sphere）(2)の理念がそれ自体理想的なものであり うるのか否か、またディスクルス（討議）・話し合いといった形の社会過程が、公論や意 見形成においていかなる役割を果たしているのか、不平等や差別の解消に本当に役立つも のであり得るのか、といった批判は核心をついている。これらの問題は確かに再検討され るべきものであろう。

にもかかわらず、こうした批判が見落としている論点もあると思われる。それは、 Habermas理論においてコミュニケーション（あるいはディスクルス）が果たすとされてい る役割、すなわち、真理を発見する装置としての、より正確には真理（正義）に接近する 装置としてのそれである。このことを見落とすと、Habermas理論がもつ規範理論としての 価值を過小評価するだけでなく、へゲモニー論が切り開く相対主義の陷突にはまる危険も 
あることを、以下の議論で示そうと思う。

\section{FraserのHabermas批判}

Fraser [1992] は、公共圈という一般的概念は批判理論にとって不可欠のものだとしつ つも、Habermasが定式化したような公共圈の概念では必ずしも満足できない、として批判 を展開している。彼女の見たところ、Habermasの『公共性の構造転換』[1962=19873] の 目的は、ブルジョア公共圈を可能にした条件を探り、その退行を描くことである。ここで のHabermasの議論によると、20世紀後半の「福祉国家のマス・デモクラシー」においては ブルジョア公共圈ないしリベラル公共圈は存立することが不可能となる。しかしFraserは、 Habermasが公共圈のブルジョア・モデルが依拠している「曖昧な前提のいくつかを明確に 問題化」しないまま、その一方で「新しいポストブルジョア的な公共圈のモデルを展開す る前で立ち止まっている」のは奇妙なことだ [Fraser, 1992: 111] という。

Habermasが導入したブルジョア公共圏の概念は、18世紀から19世紀のブルジョアジーの 自己理解から抽出されたものである。Habermas自身、ここで表明されている公共圈が当時 のブルジョアジーの間で実現されていたと主張しているわけではない。しかしそれは、単 なる自己正当化の言説という以上のものであり、ひとつの規範的理念として現実社会を照 らしだす鏡のようなものとして導入されている。Fraserも、公共圈が政治的支配を合理化 する制度的メカニズムとして作用したことは認めている。すなわち、あるレべルでは国家 を、市民に対する説明責任を負った（accountable）ものにし、別のレベルでは、ある種の 討議的な相互行為を指示するものであった。また、公共圈概念のもつ歴史的限界をも Fraserは認識している。Habermasが言うように、「公共圈のブルジョア的観念のユートピア 的潜在力が十分に実現されたことはなかった。特に誰にでも開かれた参加、という要請は 不十分であった」[Fraser, 1992: 113]。

Habermasは、公共圈が機能するには社会と国家が分離していることが重要な前提と考え ている。ところが、ブルジョアジー以外の層が政治過程に参加するようになると、この前 提は崩れてくる。「福祉国家型のマス・デモクラシーが登場し、社会と国家は相互に介入 するようになる。国家を批判的に監視するという意味での公開性は、宣伝活動（P R）、 マスメディアを通じた陳列、公論の製作と操作に道を譲ってしまった」[Fraser, 1992: 113。こうして不十分ながら規範たりうる理念として登場した公共圈が、社会・経済的条 件の変化とともにその場所を失っていく、というのがHabermasの描いた全体のストーリー である。

最近では特に社会史の研究からこうした見方に対する修正が起きている。Fraserが列举 しているところによれば、Landes, Ryan, Eleyらの研究によって明らかにされたのは、公 的な公共圈は注目すべき排除 (exclusions) に依存しており、むしろこうした排除によっ て構成されていたことである。Landes [1988］によれば、フランスにおける共和派の公共 圈は女性的なサロン文化に対抗する形で登場しており、「合理的」で「高貴」で「男らし い」スタイルが奨励された、という。Eley [1992]はイギリスとドイツにおいても同様に、 リベラルな公共圈を構成していたクラブやアソシエーションは決して誰にでも開かれてい たのではなく、「普遍的階級」であり統治するのにふさわしい者として自己主張しょうと していたブルジョアジー男性のみの排他的なものであったことを論じている。それゆえ、 
そこで論じられた言説はBourdieuのいう意味での卓越化（distinction）の戦略として捉える 必要がある。つまり、市民社会や連帯した公共圈の文化がもつ卓越性の主張は、額面通り には受け取れない [Fraser, 1992: 114-115] というのである。

ここに、公共圏の勃興に関するHabermasの説明が十分な評価を誤っている、注目すべきアイロニー がある。公開性、合理性、社会的地位ハイアラーキーの一時停止といったことを大げさに宣伝して いる公共性の言説は、それ自身卓越化の戦略として展開しているのである。[Fraser, 1992: 115]

またHabermasはリベラルな公共圏モデルを理想化しているだけでなく、それ以外の公共 圈をも見ようとしない。Ryan [1992］の研究は、公式の公共圈からは排除されていた19 世紀北米の女性が、公的な政治生活にアクセスする独自のルートを作っていたことを示し ている。したがって「女性は公共圏から締め出されていた」という見方も、Fraserによれ ば、ブルジョア公共圏こそが唯一の公共圈であるという主張を額面通りに受け入れている 点でイデオロギー的なものとされるのである。しかしながら実際は、ブルジョア公共圏だ けが唯一の公共圈（the public）であったわけではないことを、Ryanらの研究は示してい る。むしろその反対に、ブルジョア公共圈の成立とほとんど同時に「互いに競合しあう多 数の対抗公共圏 (counterpublics)」が簇生している。「国家主義者の公共圏、人民・農民的 公共圈、エリート女性の公共圏、労働階級公共圈が成立していたのだ。したがって、各公 共圏がせめぎ合うという事態は、Habermasが言うように、19世紀の終わりや20世紀になっ てはじめて現れたものではない」[Fraser，1992: 116]。

このような見方は、Habermasの提示した公共圏の理念之のものに疑いを差し挟むもので ある。つまり、公共圈の理念そのものが規範としての位置を確保しうるかどうかと言う問 題を提示しているのである。ブルジョア的公共圈の理念は「実現されなかったユートピア」 であるのか、それとも「ある階級支配の形態を正当化する機能を果たした、男権主義的な イデオロギー的観念」であるのか。Eleyは後者の立場をとっており、「公式のブルジョア 公共圏は、政治支配の性質を歴史的に大きく転換するのに貢献した制度的手段である。つ まり公共圏は、抑圧的モードの支配からへゲモニー的なそれへ、より優越した力の獲得に 基づく支配から、何らかの抑圧手段による合意に基づいた支配へ、という転換を導いたの である」。しかし注意しなければならないのは、Fraserはこの見方に全面的に賛成している わけではない、ということである。この解釈はFraserから見ても「極端すぎ、柔軟性のな い」ものである。ブルジョア公共圈のイデオロギー性を指摘して、これを放棄することに はFraser自身も反対している [Fraser, 1992: 117]。

その代わりにFraserが問題としているのは、Habermasが描くブルジョア公共圈が前提に している次の四つの点である。第一に、公共圈に参加した発話者には、地位の違いを括弧 に入れて、あたかも社会的平等者であるかのように議論することが可能だ、という前提。 この前提に従えば、社会的平等は、政治的デモクラシーの必要条件ではない、ということ になる。第二に、競合する公共圏の数が増えていくことは、デモクラシーを促進するので はなく必然的にそこから遠ざかることになり、したがって常に複数の公共圈よりも単一の 総合的公共圈の方が望ましい、という前提。第三に、公共圈での話し合いは、公的な・共 通の問題の審議に限定されるべきであり、私的利害・私的イシューが登場するのは望まし 
くない、という前提。第四に、民主的公共圈が機能するためには市民社会と国家がはっき りと分かれていなければならない、という前提 [Fraser, 1992: 117-118] である。Fraserは この四つの前提それぞれについて、その妥当性を検討して抢り、いずれの前提も疑わしい ものとして退けている。

第一に、コミュニケーションの地平は決して透明なものではなく、権力関係に彩られて いる。フェミニズムの研究が明らかにしたように、男性の方が女性の発話によう頻繁に介 入する傾向があり、女性の介入はしばしば無視され、男性の方が長く話す傾向がある。ま たコミュニケーション弱者は、自らの思考をあらわす正しい声や言葉を持ち合わせていな いことも多い。「話し合い (deliberation)」はしばしば「支配」の言い換え、という側面を もっている。政治制度は自律的だ、とリベラルは考えることが多いが、実際には自律して いないことがわかる。政治的デモクラシーが要求しているのは、実質的な社会的平等なの である [Fraser, 1992: 118-121]。それゆえむしろ、平等な話し合い・議論の空間を実現す るためにこそ、社会的平等を目指さなければならない、という要請が生じる。Fraserにと って、社会的平等は公共圈における議論の結果ではなく、むしろ前提条件である。

第二に、Habermasは公共圈をひとつに制限しょうとしており、別の公共圈が現れるとそ れは公共圈の「断片化」として衰退の印と見なしているが、これは根拠のないものである。 前述のように、抑圧されている者は自分たちの主張をするための場所を確保す方亡と自体 が困難である。女性・労働者・有色人種・同性愛者といった被抑圧階級・集団にとって対 抗的公共圈を作ることがメリットをもたらすことは、歴史的研究が繰り返し発見している ことである。例えばフェミニズム運動が、「性差別（sexism）」「セクシュアル・ハラスメ ント (sexual harassment)」等々といった抑圧状況を表現するコトバをつくり出したことを 考えてみれば、対抗的公共圈の形成が不平等・差別の解消といった目的に有効であること が理解できよう。もちろん、非民主的で差別的な対抗公共圈もありうるし、民主的・平等 主義的な対抗公共圈もインフォーマルな排除や境界維持を克服できないこともある。それ でもFraserは、階層社会と多文化社会の両方を想定した思考実験を行い、いずれの場合も 単一の公共圈よりも複数の公共圈が存在した方が望ましい、という結論を導いている [Fraser, 1992: 121-128]。

第三に、公共の事項として何を話し合うべきかは話し合いに先立って事前に決定するこ とはできない。「たとえば、ごく最近まで、女性に対する家庭内暴力を共通の問題と考え、 公共のディスクルスにふさわしいトピックであるとする点でフェミニストは少数派であっ た。大部分の人々は、この問題は極めて少数の異性カップル間（と、抢そらくこうした問 題を扱うことになっている社会的・法律的専門家）の私的な事柄だと考えていた」 [Fraser, 1992: 129]。しかしフェミニズム運動の結果、家庭内での問題も公的な問題であ る、と考えられるようになったことは記憶に新しいであろう。重要なのは、何が公的問題 で何が私的問題か、という判断の基準它のも主が人々の意識において変化している、とい うことである。それゆえ、公共圈で話し合うべきトピックをあらかじめ制限することは、 公共圈の機能を妨げることはあっても、それを促進することはないのである [Fraser, 1992: 128-132]。

第四に、市民社会（civil society）を、国家の介入を受けない資本主義経済ではなく、経 済的でも行政的でもない人々のつながり、と考えた場合、議会政治をどのように扱うかが 
問題となる。Fraserは意見形成のみに関わる公共圈を「弱い公共圈（weak publics）」、議会 政治のように意思決定まで引き受ける公共圈を「強い公共圈 (strong publics)」と命名し ているが、このように考えると公論を政治的な意思決定に結びつけることができる議会政 治は公共圈の力を強めているとも言えることになる。したがって、国家と市民社会との分 離が本当に公共圈の成立にとって不可欠であるかどうかは、議会（政府）とその外部の公 共圈との関係を再考しなければ論じられない問題である、としている。

以上の議論を通じてFraserが提案しているのは、互いに競合しあう複数の公共圈を構想 することである。このような構想のメリットは、自らの思考や利害を表明することが困難 なコミュニケーション弱者にとって存在領域を確保できる可能性があることと、あらかじ め公共圈で扱う問題を限定してしまうことを回避しやすくなることであろう。Fraserの主 張はもっぱらフェミニズムの立場からなされているというわけではないが、この見解の背 後にはフェミニズム研究によって明らかにされた知見が生かされているといえる(3)。

\section{3. 競合する公共圏のネットワーク}

Fraserによる批判は妥当な論点を多く含んでいるが、1962年に書かれた『公共性の構造 転換』を対象としたものであり、現在のHabermas理論とは相違点も多い。Habermasは 『公共性の構造転換』90年版の「序言」 [1990=1994] や『事実性と妥当性』[1992=1996] に扔いて、上述したような自らに対する批判を一部受け入れて、複数の公共圈からなるコ ミュニケーションのネットワークを構想している。Fraserの批判の問題点を指摘する前に、 現在のHabermas理論の到達点を確認しておくことも必要なプロセスであろう。

Habermasは『事実性と妥当性』第八章で、Petersのモデルを使いながら、中心 - 周縁の 軸に沿って配置され、水門（Schleuse）システムによって構造化されているコミュニケー ションのシステムを記述している。政治システムの中核領域は、行政府、司法システム、 民主的意見・意思形成という制度的複合体からなり、この中心は、形式的な意思決定権力 と実際的な特権とで周縁からは区別されている。行政の周辺では、国家によって委任され、 権利と自治あるいは監督・立法機能を持ったさまざまな制度（大学・公的保険制度・専門 家団体・慈善組織・基金等々）から、ある種の内的周縁が発達している。そして、中核領 域全体の外には、大雑把に言えば、「消費者」と「生産者」からなる外的周縁がある。そ して明確に定義された集団的利害を代表する団体や、政党政治の団体、「公的利益」を主 張する団体、協会、慈善機関等々といったさまざまなネットワークがある種の公的調整を 行っている。このような意見形成団体は、マスメディアに支配された公共圈における市民 社会の下部構造の一部、とされている [Habermas, 1992: 429-431]。

Petersの議論に依拠しながら、Habermasは意思決定に関するコミュニケーションの流れ を提示している。ここで注目されるのは「水門モデル」と呼ばれるもので、拘束力をもつ 決定は、法手続きの形で定められた中核領域の狭い水路を通らなければならない。この水 門はどのようなものでも通れる訳ではないにしても、手続的にしか決定されていないので このプロセスの方向とダイナミクスを、限られた範囲でのみコントロールするに過ぎない。 結局、具体的なコミュニケーションと意思決定のありかたは、周縁に位置している公共圈 が特定のイシューを「問題化 (Problematisierung)」することができるか否か、ということ にかかっている、というわけである [Habermas, 1992: 431-433]。 
それでは、公共圏はHabermasによってどのようなものと考えられているのであろうか。 Habermas [1992: 435-438] によると公共圏は、「社会秩序」という通常の社会学的概念で は捉えられない。これは、制度ではないし、組織でもない。公共圈は、「内的には境界を 設定することもできるとはいうものの、外的には、開かれた・浸透性の・移動する地平に よって特徴づけられる」。公共圈は、「コミュニケーションを交わす情報と視点のネットワ ークとして描写するのが最善である」。そのプロセスにおいて、「コミュニケーションの流 れは、テーマごとに特定化された公論の束となるように、フィルターにかけられ、統合さ れる」。このように、Habermasにとっての公共圈は、Fraserが想定するものよりも抽象的な 概念となっている。それは、特定の利害団体や社会運動のような実体的な人々の範用と重 なるものではなく、むしろ特定のテーマごとにそのつど現れては消えていくような何物か である。

ここでHabermasが照準を当てているのは、意思決定に結びつけられた公的な意見形成の プロセスである。「公共圈において、束ねられた意見を公論にするものは、論争的な方法 と承認である。公論は、統計学的な代表ではないし、世論調査によって発見されるような ものでもない」のである。ブルジョア公共圈の自己理解においてそうであったように、 人々の意見交換こそが公共圈を構成する実質とされている。「公共のコミュニケーション を通じて得られる政治的影響力は、究極的には共鳴に、それも、平等主義的に構成されて いる素人の承認に依存しているのである。…公的なオーディエンス（Publikum）こそが最 終的な権威なのだ。というのは、このオーディエンスこそが、行為者が登場する公共圈の 内的構造を構成しているからである」。もちろんFraserが記述しているように、われわれの 言説空間は「権力」とは無縁ではないし、「理想的発話状態」からは程遠い。例えば、大 規模でよく組織された利益集団があって、公共圏に戦略的に影響を与えようとする場合も 頻繁にある。公論が操作されうることはHabermasも認めている。しかし密かに貨幣や組織 的権力を導入することによって「公論が操作されることはあっても、公的に買収されたり、 劦迫されたりすることはない」[Habermas，1992: 440-441] のである。

要するに、HabermasはFraserのいうような多様な公共圏の概念を半分だけ認めていると 言えよう。すなわち、日常的コミュニケーションのプロセスにおいて特定の問題・イシュ 一をめぐって行われる意見の交換そのものがすでにゆるやかな公共圈を形成している。そ れは、ある特定の参加資格を得たものだけが参加できるような会合や集会のようなもので はなく、もっと日常的な通常の言葉のやりとりをも射程に含めたものである。その意味で、 Fraserのいうようにブルジョア公共圈の概念は拡張され、さまざまな場面をその中に含む ようになったといえる。しかし、Habermasもすべては譲らない。それは、Fraserの図式と は異なりテーマごとに抽象的に設定されているそれぞれのネットワークが互いに結びっ き、全体亡して一つの公共圈を作っているという主張である。つまり、さまざまな利害団 体や運動体がせめぎ合うのではなく、網の目のように張りめぐらされたコミュニケーショ ンのネットワークの中で、特定のテーマ・イシューが「問題化」され、中心の「水路」を 通って全体の意思決定に影響する、というシナリオなのである。Fraserの議論とは関心の 焦点が異なるので当然のことではあるが、Habermasの議論はあくまでも意思決定（法制定） をいかに民主的にコントロールするか、という問題に集中しており、全体としての公共圈 という想定は不可欠なのである。もちろん、だからといってFraserのいう多様な公共圈 
（話し合いの空間）が不必要ということにはならない。むしろ、Habermasの立場からすれ ば、あらゆる立場から声をあげうるということは、法制定の正義を保証する必要条件とし て要請されているといえる。

さまざまな団体によって組織される意見形成が責任ある決定につながれば、それは協力しあって真 理を探究するという目標を達成できる。ただし、それが可能であるのは、こうした意見形成のなか に、それを取り囲んでいる政治的コミュニケーションのなかで自由に漂っているさまざまな価值、 主題、論稿、論拠が入り込めるものであり続ける場合に限られる。こうした意見形成は基本的な権 利として実現されなければならない。しかし、全面的に組織することはできない。…そのさい、コ ミュニケーションの流れといっても、…意思決定ではなく発見と問題解決のための、その意味で非 組織的な公共圈のコミュニケーションの流れなのである。[Habermas, 1990=1994: xxxv]

このように、Fraserのいう「強い公共圏／弱い公共圏」という想定は、それとは違う文脈 からではあるが、「組織された公共圈／組織されない公共圈」として取り込まれているの である。

\section{4.コミュニケーションの役割：真理を発見する装置}

Eleyのように公共圈の理念そのものが卓越化戦略の産物であり、イデオロギーの言い換 えだという立場をFraserはとっていない。多岐にわたる彼女のHabermas批判をまとめると、 （1）公共圈におけるコミュニケーションの透明性、（2）公共圏の単一性、（3）公共圏 でのイシューの限定性、（4）国家と社会の分離の不可欠性、という四点に対する疑義で あった。上述したように、Habermasはある程度この批判に応える形で理論を発展させてお り、「組織された公共圈／組織されない公共圈」という図式は（2）〜（4）の批判をあ る程度受け入れたもの、と解釈することも可能であろう(4)。

しかし（1）のコミュニケーションの透明性に関しては、Habermasはその主張を貫いて いる。実際、Habermasが彼の社会理論の中核に想定しているコミュニケーション（より狭 義には討議Diskurs）の概念は、半ば超越論的に想定されているものである。現実のコミ ユニケーションや議論、意見形成・意志決定の過程がどんなに「権力」に歪められたもの であっても、あるいは、どんなに排除や抑圧といった不正義に彩られたものであっても、 根源的に想定されたこの概念を批判したことにはならない。むしろ現実がそのように歪め られているからこそ、理想的なコミュニケーションがその重要性を増してくるのである。 Habermasにとってこの概念は、抑圧された社会において認識の真理性をいかにして確保す るか、という批判理論が抱え込まざるを得ないアポリアに対処するために戦略的に採用さ れた理論装置でもある(5)。

コミュニケーション的行為という概念を導入すると、各行為者の間に言語的了解に基づ いたある秩序が成立する。了解に基づいた秩序というこのモデルは、Habermasが構築しよ うとしている社会理論にとっていくつかのメリットをもたらすものである。各行為者間の 行為計画の調整は、相互に話し合うことによって（ある程度まで）可能になる。その際、 決定的に重要なのは、各行為者がそれぞれ妥当要求（Geltungsanspruch）を掲げあい批判 可能な空間を形成する契機である。各行為者はこのコミュニケーション的行為の集積によ 
って共通の世界解釈を作り上げ、妥当する社会的規範や信頼しうる人格といった資源を再 生産しているのである [Habermas, 1981=1987（下）：44]。

ここで重要なのは、相互に調整が可能になるということだけではない。彼がこの概念に 託している役割は「ローカルな合意を超えて、真理を発見する」可能性である。もちろん、 現実のコミュニケーションにおいては、特定の発話者同士が特定の文脈において限定され た内容について合意することを目指すものである。「いまここで」揭げられた発話の妥当 要求が「相互主観的に承認・受容」されたとしても、それはせいぜい「イエス／ノーの態 度決定についての基準、つまり特定の解釈者共同体において確立されているそれ」が更新 されたことを示しているに過ぎない。しかしここで決定的に重要なのは、妥当要求にはこ うしたローカルな合意を越える「理想化する力」が組みこまれていることである。われわ れが発言において要求している妥当性は「われわれ当事者の間でだけ通用する真理」では なく、普遍的に通用するような何ものかである。言い換えれば、そうした限定的な基準が 絶えざる問い返しにさらされる可能性が開かれているということである [Habermas, 1992: 30-31]。コミュニケーションに伴ってそれまで無意識のうちに自明と考えられてきたさま ざまな前提は、繰り返し批判的吟味にさらされる。それゆえ、Habermas理論においてコミ ユニケーションという装置は、真理を発見するものとしての役割を担っている。もちろん、 各参加者はコミュニケーションの場において必ず真理に到達できるというわけではなく、 双方が真摰に話し合って誤った結論を導き出す可能性は原理的に排除できない。しかし、 ある行為者や団体・組織が単独で物事を決定し遂行していくような、批判可能性を排除し た状態を想定してみれば、見解や決定の批判可能性を原理的に確保しているコミュニケー ションは必ず真理をもたらすわけではないにしても、それに少しでも近づく（可能性をも たらす）装置として設定されていることが理解できよう(6)。

したがって、公共圏というコミュニケーションのネットワークにおいて、特定のイシュ ーが「問題化」テストをくぐり抜けていくことは、そのイシューにそれなりの説得力があ り、「公共の問題」にふさわしいと人々に考えさせる何物かを含んでいることを間接的に 証明していることになる。いわば、市民社会全体が共同で真理を探究するコミュニケーシ ヨン共同体として考えられているのである。

したがって、この見解は「へゲモニーを巡る闘争」というビジョンとは両立しうるもの の、決定的に異なるものである。もし FraserのHabermas批判から、コミュニケーションを 権力過程としての文捉えるならば、Habermasの議論がもっている中心的な意義を見落とす ことになる。例えば阿部 [1998］は、Fraserの議論がへゲモニー的なコミュニケーション 観を導いていると解釈している。

へゲモニーの問題意識がなげかけていることは、「フーコー的な意味での排除」の有無ではなく、 法的・形式的な「排除」が存在しないにもかかわらず、なにゆえに「合意」を通じて支配/従属関 係が形成されるのかという権力メカニズムの問題に他ならない。ブルジョアジーを担い手としたり ベラル・モデルを中心に、「単一的・包括的なもの」として語られるハーバーマス的な公共圈議論 に対して、「様々な対抗的公衆を担い手とした多元的な公共圈」の必要性を主張するフレイザーの 議論の意義は、公共圏に潜むへゲモニー的な権カメカニズムの側面を認識してはじめて十分に理解 可能なものとなる [阿部, 1998: 237]。 
Fraserの提起した、コミュニケーションの透明性に対する疑いは、確かにへゲモニー論 的な想定を前提にしている。このことは、現実のコミュニケーションについての経験的研 究を踏まえたものだ。この批判は、Habermasがコミュニケーションの場である「生活世界」 を「権力」と切り離された透明な空間という「フィクション」として描いてしまう、とい うHonneth [1985=1992] の批判とも共通するものである。ここから要請されるのは、表向 きは「合意」を目指して自由に話し合う空間であるかのように見えながら、実際にはコミ ユニケーション構造が「権力作用」によって歪められているのではないか、という疑いを 持ちつつ、事態を解明することである。

こうした見方は、確かに「公共圈」の現状分析として妥当なものであろう。家族関の話 し合いや小規模な会議から、国政レベルの世論形成に至るまで、われわれはもはやコミュ ニケーションや議論の透明性を信じてはいない。しかしながら、もっぱらへゲモニーの行 方を、「権力作用」のみを追い求める事は危険なことである。コミュニケーションにおけ る「合意」を「権力関係」の結果としか見ないのであれば、Habermasの中心的な主張であ るコミュニケーションと真理との結びつきは否定されることになる。あるイシューが公共 圈による「問題化」テストをくぐり抜けたとしても、それはその主張をした特定のアクタ 一がうまく P R したとか、権力を持っていたから、として処理されてしまう。こうした見 方は確かに現実の世論形成過程を分析するには有力なパラダイムとなりうるかもしれない が、Habermasの主張する規範的理念としての公共圈の価值を損なうことにもつながるので ある。むしろ規範的な鏡として「透明なコミュニケーション」という想定があるからこそ、 ヘゲモニー論がそれとして意味を持ちうる事を、われわれは銘記しておくべきであろう。

さらに、へゲモニー論はそのまま拡張していけば、自らを積極的な「真理」として主張 する土台を掘り崩してしまう恐れがある。すなわち、へゲモニー的な見解そのものが有力 に見えるのは、それが真理であるからではなく、主張者が何らかの権力をもっているから にすぎない、という自己矛盾の危険である。フェミニズム運動の結果「家庭内での夫の暴 力」は「私的なことがら」ではなく、「公的に議論するべきことがら」と思われるように なったが、それは運動が功を奏し、フェミニズム陣営が言説空間において権力を振るうこ とが可能になったからったからではなく、むしろこの主張自体に説得力があったからに他 ならない。われわれの生きているコミュニケーション空間はまったく透明ではないにして も、光が全然通らないわけではないのだ。

もちろん、「世論形成」や「意思決定」のプロセスについて実証的に研究することの意 義は損なわれない。公的な議論の文字通りの意味とは別の解釈可能性を、われわれとして も否定するつもりはない。たた、文字通りの議論そのものには二次的な意義しかないとか、 あるいは積極的な意義は全くない、といった止めどもないシニシズムの危険は常に意識し ておく必要がある。それは、このような権力政治観が、そもそもの実証的研究を支える規 範的基準を彫り崩してしまうという陥䆥をもたらすだけでなく、一行為者としてのわれわ れの政治文化に及ぼす価值的影響（ニヒリズム・政治的無関心）をも必然的に惹起するか らである。

註

(1) FraserのHabermas批判としては、Fraser [1985=1997］が全面的批判を展開しているが、本稿の考え 
る最も決定的な論点はむしろFraser [1992] が展開しているので、こちらを取り上げる。尚、Fraser [1985=1997］に関しては、Cohen [1992/95］も参照の事。

(2) Habermas [1962］の邦訳ではÖffentlichkeit の訳語は「公共性」であるが、本稿では花田 [1993] が指摘している通り、「公共圈」の方が相応しいと考えるのでこちらを用いる。ただ、書名だけは 『公共性の構造転換』のままとしている。

(3) 本稿の主題とは若干離れるが、Fraser [1985=1997] で問題とされているのは、Habermasの社会理 論が社会を「システムと生活世界」の二つに分け、もっぱらシステムからの介入のみを想定している ことである。この枠組みは性差別を問題にするには不適切であるだけでなく、生活世界内部を「権力」 とは無縁の空間として不問にし男性支配を温存させるイデオロギー的な側面をもつ、と批判されてい る。

(4)「「る程度」というのは、Habermasが「組織されない公共圏」という想定をすることで、2 ）一枚 岩的でない様々な領域からなり、3）あらかじめイシューが限定されておらず、4）国家とは独立し た公共圈（=社会）を想定しており、Fraserの批判を回避していると解釈できるからである。

(5) 批判理論の抱えるアポリアとHabermasにおけるコミュニケーションの関係については、[伊藤, 1996] で既述してある。

(6) そしてこの点がHabermas理論の評価すべきポイントであることは、Fraser [1985=1997]，Cohen [1992/1995]，Benhabib [1992］らが一致して強調している。

\section{文献}

阿部潔，1998，『公共圈とコミュニケーションー 批判的研究の新たな地平』，ミネルヴァ書房.

Benhabib,S., 1992, “Models of Public Space: Hannah Arendt, the Liberal Tradition, and Jürgen Habermas," in: Calhoun(ed.), Habermas and the Public Sphere, MIT Press, pp. 73-98.

Cohen, J., 1992, "The Historicist Critique," Cohen, J. and Arato, A.(eds.), Civil Society and Political Theory, MIT press, pp. 201-254. 1995, reprinted as "Critical Social Theory and Feminist Critiques: The Debate with Jürgen Habermas," in: Meehan (ed.), Feminists Read Habermas: Gendering the Subject of Discourse, Routledge, pp. 57-90.

Deflem, M. (ed.), 1996, Habermas, Modernity and Law, Sage.

江原由美子，1993，「自己定義権と自己決定権 一 脱植民地化としてのフェミニズム」，『岩波講座 社 会科学の方法VIII システムと生活世界』, 岩波書店, pp. 159-200.

Eley, G., 1992, "Nations, Publics, and Political Cultures: Placing Habermas In the Nineteenth Century," in: Calhoun (ed.), Habermas and the Public Sphere, MIT Press, pp. 289-339.

Fraser, N., 1985, "What's Critical About Critical Theory? The Case of Habermas and Gender," New German Critique, No. 35 (Spring/Summer 1985), pp. 97-131. = 1997, 永井務訳, 「批判理論を批判 するーハーバーマスとジェンダーの場合」，竹内真澄監訳，『ハーバーマスとアメリカ・フランク フルト学派』, 青木書店, pp. 123-170.

- , 1992, "Rethinking the Public Sphere: A Contribution to the Critique of Actually Existing Democracy," in: Calhoun(ed.), Habermas and the Public Sphere, MIT Press, pp. 109-142.

藤原保信·三島憲一・木前利秋編，1987，『ハーバーマスと現代』，新評論.

藤澤賢一郎, 1989, 「ハーバーマスの真理論」,『フランクフルト学派再考』, 弘文堂.

Habermas, J., 1962, Strukturwandel der Öffentlichkeit: Untersuchungen zu einer Kategorie der bürgerlichen Gesellschaft, Neuwied. = 1973, 細谷貞雄訳, 『公共性の構造転換』, 未来社.

— , 1981, Theorie des kommunikativen Handelns, 2Bd., Suhrkamp. = 1985/86/87, 平井俊彦・フーブ リヒト・河上倫逸・徳永恂・脇圭平他訳, 『コミュニケイション的行為の理論 上・中・下』, 未来 社.

一， 1983, Moralbewußtsein und komminikatives Handeln, Suhrkamp, = 1990, 三島憲一・中野敏男 · 木前利秋訳，『道徳意識とコミュニケーション的行為』，岩波書店. 
— ， 1988, Nachmetaphysisches Denken: Philosophische Aufsätze, Suhrkamp. = 1990, 藤沢賢一郎 · 忽那敬三訳, 『ポスト形而上学の思想』，未来社.

— , 1990, “Vorwort zur Neuauflage 1990,” in: Strukturwandel der Öffentlichkeit (Auflage 1990) $=1994$, 山田正行訳「一九九 $\bigcirc$ 年新版への序言」, 『公共性の構造転換 第 2 版』, 未来社.

- 1992, Faktizität und Geltung: Beiträge zur Dirkurstheorie des Rechts und des demokratischen Rechtsstaats, Suhrkamp. $=1996$, Rehg, W. (tr.), Between Facts and Norms: Contributions to a Discourse Theory of Law and Democracy, MIT Press.

— , 1996, Die Einbeziehung des Anderen: Studien zur politischen Theorie, Suhrkamp. = 1998, Cronin, C. \& De Greiff, P. (ed. \& tr.), The Inclusion of the Other: Studies in Political Theory, MIT Press.

花田達朗, 1993, 「公共圈と市民社会の構図」, 『岩波講座 社会科学の方法VIII システムと生活世 界』，岩波書店, pp. 41-83.

Honneth, A., 1985, Kritik der Macht, Suhrkamp, = 1992, 河上倫逸監訳, 『権力の批判』, 法政大学出 版局.

伊藤賢一， 1996，「批判的社会理論の存立条件 一 Habermas理論のbreakthrough」，『ソシオロゴス』20 号, pp. 1-16.

ジェイ編, 1997, 竹内真澄監訳, 『ハーバーマスとアメリカ・フランクフルト学派』, 青木書店.

Landes, J., 1988, Women and the Public Sphere in the Age of the French Revolution, Cornell Univ. Press. McCarthy, Th., 1992, "Practical Discourse: On the Relation of Morality to Politics," in: Calhoun (ed.), Habermas and the Public Sphere, MIT Press, pp. 51-72.

Ryan, M. P., 1992, "Gender and Public Access: Women's Politics in Nineteenth-Century America," in: Calhoun (ed.), Habermas and the Public Sphere, MIT Press, pp. 259-288.

White, S. (ed.), 1995, The Cambridge Companion to Habermas, Cambridge Univ. Press. 